\title{
Impact of small business management on optimizing business performance (Study on small-scale cake businesses in Sarolangun District)
}

\author{
Candra Mustika*; Sigit Indrawijaya; Zamzami \\ Faculty of Economics and Business, Universitas Jambi, Indonesia \\ *To whom correspondence should be addressed. Email: candra.mustika@yahoo.com
}

\begin{abstract}
The purpose of this research is to analyze the corporate governance of Small and Medium-sized Enterprises (SMEs) in Creative Industry from the aspect of industrial profile, financial management, human resources management, operational management and marketing management in Sarolangun District. The population in this study was a group of Small and Medium Industries in Sarolangun District. This study examined 100 companies belonging to the SMEs. Primary data collection is carried out using questioner instrument and Focus Group Discussion techniques by involving stakeholders including business actors, government, academics and consumers. Descriptive analysis approach and statistical analysis/verification also used in this study. SWOT analysis is used for quantitative approach on the other hand matrix were used for qualitative approaches. The weighting and categorization of the results of the research variables suggests that financial management is in good category, marketing management is in good category, human resource management is in good category, operational management is not in good category and lastly business performance is in good category. The results of the SWOT diagram prove that the management position of the small-scale cake maker in Sarolangun District is currently in quadrant I, meaning that small-scale cake-making businesses in Sarolangun District already have the power and opportunity to improve business performance, thus the right strategy to improve the current business performance is through aggressive strategy.
\end{abstract}

Keywords: management, small enterprises, business performance

JEL Classification: M21, L25, L26

\section{INTRODUCTION}

The contribution of small businesses in Indonesia is very large. Indonesia's Gross Domestic Product (GDP) continues to increase every year. Small businesses play a huge role in efforts to improve the economy in both developed and developing countries. In developed countries, small businesses are very important because the business group absorbs the most workforce and also on the other hand its contribution to the formation or growth of gross domestic product (GDP) is the biggest compared to the contribution of businesses big.

The platform in government policy to encourage small and medium enterprises in Indonesia is through the Law No. 20 of 2008 concerning Micro, Small and Medium Enterprises, in this effort needs to be carried out comprehensively, optimally, and sustainably through the development of a conducive climate, providing business opportunities, support, protection and business development to the widest possible 
extent. Small businesses are expected to be able to improve their position, role and potential, as contributed by large businesses in realizing economic growth, equity and increasing people's income, creating jobs, and alleviating poverty.

Efforts that have been made by the government and other elements in society to encourage the community's economy towards a better one have been carried out, especially in terms of funding. However, the problem faced is not solely a matter of funds even though funds are still needed by small businesses. The fact that we see that most small businesses are very difficult to develop and can barely survive. Other factors such as the management of the customer, input, process, and relatively low output quality are thought to be the causal factors. Therefore, for small businesses to be optimal, management implementation must be pursued so that it can ultimately have an impact on improving business performance for small businesses.

In an effort to improve the performance of businesse, it is necessary to conduct proper management of small businesses in Sarolangun District, especially for the cake industry. For this reason, studies must be carried out to provide an overview to what extent the impact of small business management on business performance improvement in Sarolangun District.

This research is examines the impact of small-scale business management in terms of financial, human resources, operations and marketing management so that a comprehensive management system can be formulated to improve the performance of small businesses, especially cake makers in the Sarolangun District.

\section{LITERATURE REVIEW}

According to Law No. 9 of 1995, small businesses are economic activities carried out by individuals or households or an entity, aiming to produce goods or services commercially traded, which have a net worth of at most Rp. 200 million, and have annual sales value of Rp. 1 billion or less.

Whereas based on the Decree of the Minister of Industry and Trade No. 589/MPP/KEP/10/1999 explained that small industry is an industrial business activity that has an investment value of up to Rp. 200.000 .000 (two hundred million) excluding land and buildings for business. Whereas small and medium industries are industrial businesses with a value of investment of up to Rp. 1.000.000.000 (one billion) excluding land and buildings for business.

In Presidential Instruction Number 10 of 1999, it is stated that the characteristics of medium-sized businesses are as follows: have a net worth greater than Rp. 200,000,000 (two hundred million rupiah) up to a maximum of Rp. 10,000,000,000 (ten billion rupiah), not including land and building of business premises; owned by Indonesian Citizens; stand alone and not a subsidiary or branch of the company owned, controlled or affiliated directly or indirectly with large businesses; in the form of an individual business entity, a business entity that is not a legal entity and or a legal entity.

In Indonesia the characteristics of small businesses are divided into two parts. The first is the unique characteristics and advantages of the small business. Some of the characteristics of this business include: (1) the scale of small businesses both in terms of capital, labor and market, generally in rural areas, small towns or large suburbs with private ownership status, (2) the status of private and family owned businesses, (3) Labor sources originate from a socio-cultural environment (ethnic or geographical), (4) work patterns are often part-time or in the form of a side business, (4) simple and limited business management in adopting technology, (5) very dependent on sources of own capital, (6) often do not have a business license and business requirements are not 
met, (7) corporate strategies often depend on the environment (Sucherly, 2003).

Prawiranegara (1998) argues that small businesses play an important role in driving Indonesia's economic growth. There are several reasons underlying this statement, including: (1) quantitatively their numbers are quite large, the majority of them directly serve the daily needs of the wider community. In developed countries, the average SMEs is more than 90 percent of all business units. Second, their total assets have a significant contribution and potential to the national economy.

Some research results found that there were various problems faced by SMEs in their efforts to develop themselves. UIEU SMEs Study Center, May 2008 explained that out of 30 SMEs coached by UIEU SMEs Study Center found that the order of small business problems was: financial management, marketing, labor and production.

Meanwhile, according to Tambunan (2004), stated that even though the amount of capital flows is large enough to small businesses, if it is not followed by guidance, especially on how to use the assistance received, small businesses tend to be unsuccessful. In terms of finances, there are actually many parties that have helped small businesses. In the financial context, various parties must understand that the problems of small businesses are not solely related to financial or capital issues. Many also have problems outside the capital sector. In this context, what is needed by small businesses like this is not only capital, but coaching.

According to Crowther and Seifi (2010), there are 4 (four) principles of good corporate management, namely: transparency (transparency), which means companies must be transparent with all governance procedures; accountability, which means the structure of the financial statements must be clear; responsibility, which means that someone must be responsible for actions taken; fair (fairness), which means that the company system must run fairly, namely not taking sides with anything and without prejudice with anyone.

According to Lumpkin and Dess (1996), performance is a multidimensional concept and the relationship between entrepreneurial orientation and performance can depend on the indicators used to access performance. Many empirical studies have reported the many different performance indicators (for example the studies of Venkataraman and Ramanujam, 1986); generally is the difference between the size of financial performance and non-financial performance. Non-financial performance measurement measures the business goals (goals) such as satisfaction and the level of success in the global scope that can be achieved by the owners or managers; financial performance indicators measures factors such as sales growth and ROI. According to Murphy, Trailer and Hill (1996), with regard to financial performance, there is often a low convergence between different indicators.

Business performance variables have indicators of sales growth, capital growth, labor growth, market growth and profit growth. Business performance is described as an achievement obtained by a business organization (Musran Munizu, 2010).

According to Zahra and Covin, (1995), the main conceptual regarding the relationship between entrepreneurial orientation and performance focuses on the financial aspects of performance. Businesses that have high entrepreneurial orientation can target premium market segments, set high selling prices and occupy a market position that is superior to its competitors, which will certainly generate greater profits and can be quickly to expand.

Muzzafar et al., (2009), explores the performance of successful small business enterprises characterized by innovation behavior and risk takers. There are three categories that influence the success of this business such as the characteristics of the 
entrepreneur, the initial behavior and overall corporate strategy.

To support this second year research, the first year research has been carried out which results in financial management, human resource management, operational management and marketing management carried out together by cake makers in Sarolangun District have a significant influence on business performance variables, as well as partially all research variables $(\mathrm{X} 1=$ financial management, $\mathrm{X} 2=$ human resources management, $\mathrm{X} 3=$ operational management and $\mathrm{X} 4=$ marketing management) have a significant effect on $\mathrm{Y}$ (the performance of cake businesses).

Research results related to SMEs have been widely carried out by researchers both at national and local levels. Several studies that have been conducted relating to Small and Medium Enterprises (SMEs) in Sarolangun include research conducted by Ade Octavia et al (2012), concerning Evaluation of Micro, Small and Medium Enterprises Receiving Government Assistance and Strategies for Increasing Business Competitiveness in the context of Encouraging the Economy of Jambi Province, concludes that capital is not the only inhibiting factor in the development of cooperatives.

Research conducted by Dahmiri et al (2013) on improving the competitiveness of Small and Medium Enterprises in Sarolangun District concluded that the level of competitiveness of Small and Medium Enterprises in Sarolangun District were still low. The competitiveness indicator includes access to businesses, markets, human resources and technology.

Good governance principles for corporations includes transparency, accountability, responsibility and fairness. The governance of SMEs, especially cake makers in Sarolangun District, has not yet used the principles of corporate governance. Therefore, cake businesses can grow and develop without dealing into bigger problems, it is necessary to adopt the principles of corporate governance (Crowther and Seifi, 2010). Whereas (Mulbert, 2010) and Stapledon (1997) explain that corporate governance includes shareholders, management led by the Chief Executive Officer (CEO) and the board of directors.

\section{RESEARCH METHODS}

\section{Data source and method of data collection}

Primary data is obtained directly from the field survey, namely the SMEs managers/actors, as well as from stakeholders related to other creative industries. Secondary data is obtained from the Department of Industry and Trade of Jambi Province and Regency/City, the Office of Cooperatives and SMEs of Sarolangun District, the Central Statistics Agency, the Department of Tourism and literature studies. Data collection is done by structured interviews, observations and documentation.

\section{Population and sample}

Population is a collection of all elements, in this case is defined as the object of research (Supranto, 1994). The population in this study is a group of Small and Medium Industries in Sarolangun District.

The sampling technique used in this study is purposive sampling. A purposive sample is a sample that is carefully chosen so that it is relevant to the research. Sampling with this aiming technique is good because it is in accordance with the researchers' own considerations so that it can represent the population. The advantage lies in the accuracy of the researcher choosing the data source according to the variables studied. (Sutrisno, 1992). 
Provisions on the number of samples based on the opinion of Singarimbum (2008) which said the smallest sample is $\leq 30$. This study will examine 100 companies belonging to the Small and Medium Industry (SMEs) group, with 100 respondents in which each company consists of 1 respondent, the owner business.

\section{Data analysis method}

Primary data collection was carried out with Focus Group Discussion (FGD) techniques involving stakeholders including business people, government, academics and consumers. The data collected were processed, by doing data tabulation first, data collection is done through questionnaires, to test validity the questionnaire were carried out by two types of testing, namely the test of validity and test of reliability. In analyzing and interpreting data and information in this study, the author uses a descriptive analysis approach and statistical analysis/verification method.

\section{RESULTS AND DISCUSSION}

\section{Overview of respondent}

Data from the Industry and Trade Office of Sarolangun District in 2015, the number of Small Businesses especially Cake Producers in Sarolangun District were counted as many as 96 units. Referring to the opinion of Arikunto (2002), if the subject is less than 100 respondents, it is better to take it all so that the research is categorized as population.

The majority of the businessmen in the cake-making business in Sarolangun District are men amounting to $85 \%$, whereas women are only $15 \%$. Various of chips and crackers dominates the cake industy by $58 \%$, and as many as 51 people or $52 \%$ of the total respondents of cake producers businesses were located at Sarolangun District, whereas $88 \%$ of the cake businesses only consist of 1-5 employees.

\section{Small enterprises management towards improvement of business performance}

Based on Figure 1, which explains the supporting factors of small business management in improving business performance on average is at the number 2.9 or categorized as good. It was found that the financial management factors and small business marketing management in the cake crafters were in good condition, meaning that in running a small cake maker business in Sarolangun District had operate financial management which included managing business capital sources, small business models, low operating costs, having assets that are used for business, recording revenue and expenditure of business finance, which suggests in accordance with good business governance. Likewise in marketing management which includes presenting good products and quality pricing that is able to compete in the market, executing product promotion to attract customers and determining the right place to sell its products, it has also been done by cake makers quite well.

The human resource management factors include human resources planning both from recruitment, selection and placement of human resources, determining the wages of workers, utilizing labor from the family environment, still have not been implemented by cake makers businesses. Likewise, the factors of business operational management which include determining production capacity, determining strategic business locations, making business layout but being non-permanent and determining the basis of work flow but still simple, have also not been carried out by the cake makers in Sarolangun District. 


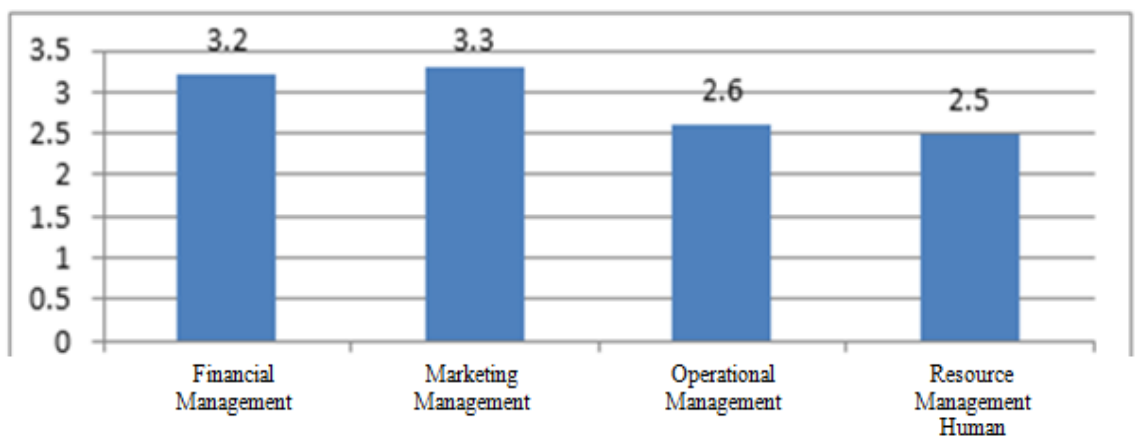

Figure 1. Factors of good management in improving business performance

However, when viewed from the business performance factors that have been achieved by the cake craftsmen include earning profit, there has been a development of turnover and the size of business which is marked by an increase in the number of assets, capital and labor, has entered the category of good, meaning the small-scale cake-maker business is quite successful in achieving good business performance.

\section{Managing small enterprises to improve business performance}

The constraint that still faced by small-scale cake-making businesses in Sarolangun District in improving business performance are in the human resource management and operational management. HR management is still a constraint, among others, the lack of good HR planning, including recruitment, selection and placement of human resources, labor wages and very family-dependent of workforce which lacking of quality. Operational management which is also a constraint for cake makers, among others, is the lack of management of production capacity, unlclear strategy of business locations, no business layout and unclear work flow.

The business challenges in the future are getting tough, the Asean Economic Community is a signal that businesses must immediately rise and must be able to compete globally. To face the challenges of the Asean Economic Community, small businesses must be able to create quality products and good business performance. From the current small business conditions, it is necessary to make an internal and external factor analysis, where internal conditions describe strengths and weaknesses and external factors involve threats and challenges and are given weight to see whether the strength is greater than weakness and vice versa. The purpose of this analysis is to improve the performance of small-scale cake makers. Furthermore, internal and external factors can be seen in Tables 1 and 2 .

Table 1.Internal factors which explains strengths and weaknesses of small-scale cake businesses

\begin{tabular}{llccc}
\hline No. & \multicolumn{1}{c}{ Strength } & Value & Rating & Score \\
\hline 1. & Raw material availability & 0,1 & $4 / 4$ & 0,4 \\
2. & Labour availability & 0,1 & $4 / 4$ & 0,4 \\
3. & Creativity & 0,25 & $3 / 4$ & 0,75 \\
4. & Capital power & 0,05 & $3 / 4$ & 0,15 \\
\hline \multicolumn{2}{r}{ Total strengths from internal factors } & & 1,70 \\
\hline No. & Weakness & Value & Rating & Score \\
\hline 1 & Business knowledge & 0,2 & 3 & 0,6 \\
2 & Tech savvy & 0,2 & 2 & 0,4 \\
3 & Product quality standart & 0,1 & 0,4 \\
\hline \multicolumn{2}{r}{ Total weaknesses from internal factors } \\
\hline
\end{tabular}

Differences between $\mathrm{O}-\mathrm{T}=1.6-1,5=0,3$ 
Table 2. External factors which explains opportunity and threats of small-scale cake businesses

\begin{tabular}{llccc}
\hline No. & \multicolumn{1}{c}{ Opportunity } & Value & Rating & Score \\
\hline 1 & Capital support & 0,15 & 4 & 0,6 \\
2 & Opportunity of new market & 0,05 & 3 & 0,15 \\
3 & Access to technologies & 0,05 & 3 & 0,15 \\
4 & Conducive Business environment & 0,25 & 4 & 1,0 \\
\hline \multicolumn{2}{r}{ Total opportunity from external factors } & & 1,9 \\
\hline No. & \multicolumn{1}{c}{ Threat } & Value & Rating & Score \\
\hline 1 & Competitive pricing & 0,2 & 3 & 0,6 \\
2 & Competitive product quality & 0,15 & 3 & 0,45 \\
4 & Competitor's product variety & 0,1 & 4 & 0,4 \\
5 & Competitor's technological advantage & 0,05 & 4 & 0,2 \\
\hline \multicolumn{2}{r}{ Total threat from external factors } \\
\hline
\end{tabular}

Differences between $\mathrm{O}-\mathrm{T}=1,9-1,65=0,25$

Based on the condition of internal factors in Table 1 and external factors in Table 2 , it can be seen at this time that the position of small-scale cake makers has the advantages and opportunities described in the figure 2. From the results of the SWOT diagram, we obtained that the management position of the small-scale cake maker in Sarolangun District is currently in quadrant I, meaning that small-scale cake-making businesses in Sarolangun District already have the power and opportunity to improve business performance, thus the right strategy required to improve the business performance is an aggressive strategy.

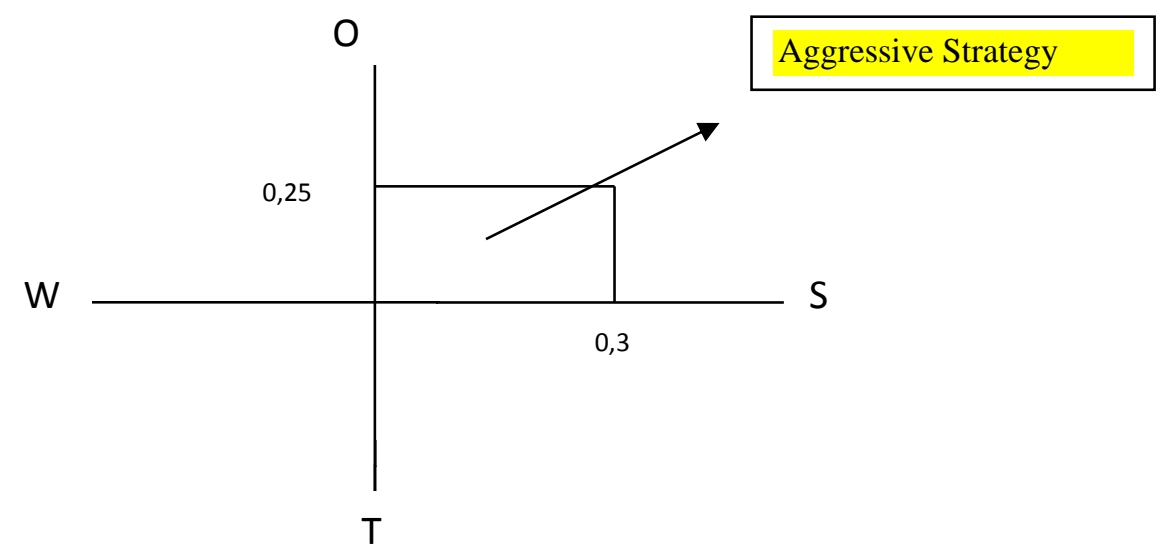

Figure 2. SWOT diagram of cake making industry for small enterprises management

Apart from the SWOT diagram, we also formulate it into the SWOT matrix, which can be seen in the following table:

Table 3. Combined strategy formula SWOT Matrix

\begin{tabular}{|c|l|l|}
\hline EFAS & \multicolumn{1}{|c|}{ Strength $(\mathbf{S})$} & \multicolumn{1}{c|}{ Weakness $(\mathbf{W})$} \\
\hline Opportunities $(\mathbf{O})$ & $\begin{array}{l}\text { Strategy }(\mathrm{SO}): \\
=1.70+1.90=3.60\end{array}$ & $\begin{array}{l}\text { Strategy }(\mathrm{WO}): \\
=1.4+1.90=3.3\end{array}$ \\
\hline Threats $(\mathbf{T})$ & $\begin{array}{l}\text { Strategy }(\mathrm{ST}): \\
=1.7+1.65=3.35\end{array}$ & $\begin{array}{l}\text { Strategy }(\mathrm{WT}): \\
=1,4+1.65=3.05\end{array}$ \\
\hline
\end{tabular}

IFAS : Internal strategic factor analysis summary

EFAS: External strategic factor analysis summary 
The SWOT matrix strategy in the table shows that small-scale cake-maker businesses in Sarolangun District need to utilize the SO strategy that has the highest score of 3.60, followed by ST strategy $=3.35$, WO strategy $=3.3$, and WT strategy $=$ 3.05 .

The results of the SWOT analysis in Figure 2 where the position of the smallscale cake-making business in Sarolangun District is in quadrant I, meaning that smallscale cake-making business has the advantage of strength-side and can be used to explore opportunities. Therefore, small-scale cake crafters must carry out aggressive strategies. Thus an aggressive strategy through internal factor analysis and external factors analysis can be formulated as follows:

Table 4. Aggressive strategy through internal and external factors analysis

\begin{tabular}{|c|c|c|}
\hline External & $\begin{array}{l}\text { Strength (S) } \\
\text { 1. Raw material availability } \\
\text { 2. Labour availability } \\
\text { 3. Creativity } \\
\text { 4. Capital power }\end{array}$ & $\begin{array}{l}\text { Weakness }(\mathbf{W}) \\
\text { 1. Business knowledge } \\
\text { 2. Tech savvy } \\
\text { 3. Product quality standart }\end{array}$ \\
\hline $\begin{array}{l}\text { Threat (T) } \\
\text { 1. Competitive Product Pricing } \\
\text { 2. Competitor's Product Quality } \\
\text { 3. Competitor's Wide Variety of } \\
\text { Products } \\
\text { 4. Competitor's technology }\end{array}$ & $\begin{array}{l}\text { Managing ST } \\
\text { 1. Government creating clusters } \\
\text { for small enterprises } \\
\text { 2. Government and private } \\
\text { supports continuous } \\
\text { development for small } \\
\text { enterprises } \\
\text { 3. Government and private } \\
\text { provides capital support for } \\
\text { small cake businesses }\end{array}$ & $\begin{array}{l}\text { Managing WT } \\
\text { 1. Government provides market } \\
\text { access to increase income for } \\
\text { cake businesses } \\
\text { 2. Provides technological } \\
\text { support and knowledge to } \\
\text { adapt in the changing } \\
\text { environment } \\
\text { 3. Provides specific services for } \\
\text { Product Certification and } \\
\text { business license for small } \\
\text { cake businesses }\end{array}$ \\
\hline $\begin{array}{l}\text { Opportunity (O) } \\
\text { 1. Capital Support } \\
\text { 2. New market opportunities } \\
\text { 3. Access to technology } \\
\text { 4. Conducive business } \\
\text { environment }\end{array}$ & $\begin{array}{l}\text { Managing SO } \\
\text { 1. Develop local potential in the } \\
\text { utilization of local raw } \\
\text { materials and manpower } \\
\text { 2. Creating conducive business } \\
\text { environment }\end{array}$ & $\begin{array}{l}\text { Managing WO } \\
\text { 1. Improve supporting and } \\
\text { training methods to face } \\
\text { competitive market } \\
\text { 2. Incentivize cake businesses to } \\
\text { be more creative and } \\
\text { innovative to increase } \\
\text { competitive advantage. } \\
\end{array}$ \\
\hline
\end{tabular}

\section{CONCLUSION AND RECOMMENDATIONS}

\section{Conclusion}

The majority of the businessmen in the cake-making business in Sarolangun District are men amounting to $85 \%$. Various of chips and crackers dominates the cake industy by $58 \%$, and the $52 \%$ of cake industry distribution is in Sarolangun District, whereas $88 \%$ of the cake businesses only consist of $1-5$ employees. Weighting and categorization of the research result suggest that financial management is good, marketing management is good, human resource management is good, operational management is not good and business performance is quite good.

From the results of the SWOT diagram, information was obtained that the management position of the small-scale cake maker in Sarolangun District is currently in quadrant I, meaning that small-scale cake-making businesses in Sarolangun District already have the power and opportunity to improve business performance, for that the right strategy for improving business performance is to utilize an aggressive strategy. 


\section{Recommendations}

The actors of the cake-making business in Sarolangun Regency always try to improve all the variables of good management of financial, HR, marketing management even though the current category is quite good. Operational management as a variable is a concern because this variable is not good enough and must be improve in the future. Other researchers are advised to include other variables so as to produce more accurate, more varied and more profound findings relating to business performance.

\section{REFERENCES}

Arikunto, S. (2010) Prosedur penelitian suatu pendekatan praktik. Jakarta: Rineka Cipta

Crowther, D., Seifi, S. (2010). Corporate Governance and Risk Management.Ventus Publishing ApS.

Dahmiri (2013), Upaya peningkatan daya saing Usaha Kecil dan Menengah di Kabupaten Sarolangun. Sarolangun Jambi.

Instruksi Presiden Republik Indonesia. Nomor 10 Tahun 1999. Tentang. Pemberdayaan Usaha Menengah.

Jogiyanto, 2010, Sistem Informasi Strategik untuk Keunggulan Kompetitif, Penerbit Andi Offset, Yogyakarta

Lumpkin, D.T, Dess, GG (1996), "Clarifying the entrepreneurial orientation construct and iinking it to performance", Academy of Management Revzew, Vol. 21, pp. 135-72.

Mulbert, P. O. (2010). Corporate Governance of Banks after the Financial CrisisTheory, Evidence, Reforms. ECGI Law Working Paper.

Muzaffar, Ahmed T, (2009), entrepreneurs of the street, an analytical work on the street food vendor of dhaka city, International Journal Of Business management, vol.4 No.2.

Murphy, B.G., Trailer, W.J., and Hill, C.R., 1996. Measuring Performance in Organizational Level Analysis. Journal of Business Reserch, Vol. 36, 15-23.

Munizu, M. (2010). Pengaruh Penerapan Praktik Total Quality of Management (TQM) Terhadap Kinerja Kualitas (Studi Persepsi Karyawan pada PT. Sermani Steel Makassar). Skripsi. Fakultas Ekonomi Universitas Hasanuddin.

Octavia. A. et.al (2012), Evaluasi Usaha Mikro Kecil dan Menengah Penerima Bantuan Pemerintah dan Strategi Peningkatan Daya Saing Usaha Bersangkutan Dalam Rangka Mendorong Perekonomian Provinsi Jambi.

Prawiranegara AS, 1998, Kebijaksanaan Pembinaan Pengusaha Kecil Khususnya Tentang Organisasi Usaha di Indonesia”, dalam Jurna 1 Ilmu-Ilmu Sosial,

Pengusaha Kecil : Penting dan Kompleksitas Masalahnya, Jakarta : PAU-ISUI, November 1994.

Rangkuti, F, 2006, " Analisis SWOT Teknik Membedah Kasus Bisnis,PT. Gramedia Pustaka Utama, Jakarta.

Singarimbun, Peter H dan Chris M. 2008. "Penentuan Variabel dan Hubungan Antar Variabel". in Singarimbun, Masri dan Sofian Effendi (ed.). Metode Penelitian Survei. Edisi Revisi. Cetakan ke-19. Jakarta: Pustaka LP3ES (hal. 122-146).

Sutrisno, H, 1992, Statistik 2, Yogyakarta, Penerbit Andi, Yogyakarta

Sucherly (2003), Peranan Manajemen Pemasaran Stratejik dalam Menciptakan 
Keunggulan Posisional serta Implikasinya terhadap Kinerja Organisasi Bisnis dan Non Bisnis (Pendekatan 5-A). Orasi Ilmiah. Universitas Padjajaran, Bandung.

Supranto, J. 1994. Statistik: Teori dan Aplikasi Jilid 2 (cetakan 5). Jakarta: Erlangga Stapledon, G.P. (1997). Institutional Share holders and Corporate Governance. Otago Law Review, Vol.9, No.1, pp. 177-179.

Tambunan, M (2004). Melangkah ke depan UKM dalam Perekonomian Indonesia di masa depan, Makalah pada Debat Ekonomi ESEI, 2004, Jakarta Convention Centre, 15-16 September 2004.

Undang-Undang Nomor 20 Tahun 2008 Tentang Usaha Mikro Kecil dan Menengah, Depkumdang dan HAM, Jakarta

Undang Undang No. 9 Tahun 1995. Tentang: Usaha Kecil. Oleh. : Presiden Republik Indonesia. Nomor. : 9 Tahun 1995 (9/1995). Tanggal. : 26 Desember 1995 (Jakarta). Sumber. : LN 74; TLN 3611. Presiden Republik Indonesia.

Venkatraman, N. And V. Ramanujam, 1986. Measurement of Business Performance In Strategy Reasearch: A Comparison Approaches, Academy of Management Review, Vol. 11, pp.801-814.

Zahra, S.A., \& Covin, J. (1995). Contextual Influences on the Corporate Entrepreneurship-Performance Relationship: A Longitudinal Analysis. Journal of Business Venturing, 10, 43-58. 